\title{
Experimental Analysis on Performance and Emission Characteristics of C.I. Engine Fueled by Neem Oil Biodiesel with Additive
}

\author{
A. S. V. Prasad, G. Venkateswara Rao, A. Rama Krishna, B. Srikanth
}

\begin{abstract}
In this present work, experiments were conducted on a VCR Diesel engine with diesel, Neem oil biodiesel and Di-ethyl ether mixed with neem oil biodiesel. The performance and emission characteristics were evaluated and compared. The study shown that the Brake thermal efficiency increased and the brake specific fuel consumption reduced with B10 blend of neem oil biodiesel compared to diesel. The emissions of $\mathrm{CO}, \mathrm{CO}_{2}$ were reduced but $\mathrm{HC}$ and smoke were increased with the use of biodiesel than diesel. The addition of Diethyl Ether (DEE) further improved the performance and decreased the emissions of $\mathrm{CO}$ and $\mathrm{CO}_{2}$ of the engine at B20DEE20 blend compared to other blends of biodiesel and diesel.
\end{abstract}

Keywords: Neem oil, Diethyl Ether, performance, emissions, diesel, VCR Engine.

\section{INTRODUCTION}

Diesel engines are mostly used power generating units in developing countries like India because of their high thermal efficiency, low fuel consumption rate and high torque compared to petrol engines. Also the rise in petrol price made diesel fuel more affordable. The day to day rise in pollution and reduction of crude petroleum resources make us go towards new and renewable fuel systems. Biodiesels are one of such fuels using which the quantity of diesel consumption can be reduced without any major changes in engine design [1]. Many researchers [2-6] conducted experiments on C.I. Engines with the methyl esters of vegetable oils which are edible in nature and proved that these oils blended with diesel can reduce emissions and increase performance.

But the usage of edible oil as biodiesel may affect the food chain by replacing the cultivation lands of food with oil crops. This leads to food versus fuel situation. This could damage the eco system and economy of the world [7]. On the other hand non-edible oils can be converted into biodiesel

Revised Manuscript Received on February 05, 2020.

* Correspondence Author

A. S. V. Prasad*, Department of Mechanical Engineering, B V C Engineering College, Odalarevu, A.P., India.

G. Venkateswara Rao, Department of Mechanical Engineering, B V C Engineering College, Odalarevu, A.P., India.

A. Rama Krishna, Department of Mechanical Engineering, B V C Engineering College, Odalarevu, A.P., India.

B. Srikanth, Department of Mechanical Engineering, B V C Engineering College, Odalarevu, A.P., India.

(C) The Authors. Published by Blue Eyes Intelligence Engineering and Sciences Publication (BEIESP). This is an open access article under the CC BY-NC-ND license (http://creativecommons.org/licenses/by-nc-nd/4.0/) due to their similar properties to that of edible oils, yield and availability [8].

The too high viscosity of vegetable oils both edible and non-edible oils cause its direct usage in C.I. engines not possible. The viscosity of oil can be reduced by the number of methods like dilution, micro emulsification, pyrolysis and transesterification. Among them the base catalytic transesterification method is preferred in this study as it is economical, faster reaction, operating at normal pressure and not too high temperature is required [9]. Transesterification is the process of converting the long chains of glyceride into fatty acid alkyl esters. The properties of oil after transesterification are very close to the conventional diesel fuel [10].

S. Jaichandar et al [11] have conducted experiments on a single cylinder 4 stroke C.I. Engine with Jatropha biodiesel. Their results have shown that a blend of $20 \%$ biodiesel given $17.9 \%$ reduction in $\mathrm{HC}, 16 \%$ reduction in CO, and $21 \%$ reduction in smoke. However the Brake thermal efficiency reduced by $2.8 \%$ at that blend. T. Venkateswara Rao et al [12] have studied the performance and emissions of single cylinder 4-stroke C.I. Engine with Pongamia, Jatropha and Neem methyl esters. They observed in their study the Brake thermal efficiency of all these oils was slightly less than that of diesel. The brake thermal efficiency at $20 \%$ biodiesel was comparable with diesel. The CO, HC and Smoke emissions were reduced with $10 \%, 20 \%$ and $40 \%$ blends of these oils. Jayashri N. Nair et al [13] have conducted experiments with neem oil biodiesel on C.I. Engine with 10\%, 20\% and 30\% blend ratios. The results of their tests showed an increased Brake thermal efficiency with neem oil biodiesel. The BSFC, emissions of $\mathrm{CO}, \mathrm{HC}$, NO, and smoke were considerably reduced at $10 \%$ neem oil blend.

Many researchers have conducted experiments with biodiesels and most of the results suggested that the usage of $10 \%$, $20 \%$ and $30 \%$ of biodiesel contributes better combustion, performance and emission parameters of the diesel engine [14-17].

In order to improve the C. I. Engine performance further, some methods are adopted like using the chemical additives, nano powder additives that are mixed directly to the diesel or biodiesel, exhaust gas recirculation etc...Significant work is done with biodiesels by adding chemical additives such as diethyl ether, n-butanol, di-tert butyl peroxide, ethyl hexyl nitrate, dimethyl carbonate etc. to improve the performance and emission reduction. 
M. Vijay Kumar et al [18] reviewed the articles published on biodiesels added with different metal based additives, oxygenated additives, cetane number improver additives and antioxidant additives. They concluded that the addition of these additives in biodiesel given significant improvement in performance and reduction in emission. M. Mohamed Mustafa et al [19] have compared the performance and emissions of C. I. Engine with palm biodiesel with and without Di-tert-butyl peroxide (DTBP) additive. They observed an addition of $1 \%$ DTBP by volume with biodiesel enhanced the performance of the engine and reduced the $\mathrm{NOx}$ emissions. S. Imtenan et al [20] have studied the emission and performance parameters by mixing palm biodiesel with n-butanol, Diethyl ether and ethanol. The brake power and Brake thermal efficiency of the engine Improved with these additives and Brake specific fuel consumption and Carbon monoxide emission were reduced. However $\mathrm{HC}$ and NO emissions were increased with the usage of additives.

Swarup Kumar Nayak et al [21] investigated the performance and emissions of a diesel engine with Mahua biodiesel with Dimethyl carbonate as an additive. The results shown that the emissions of $\mathrm{CO}, \mathrm{HC}$ were decreased and smoke, NOx emissions were increased compared to the biodiesel without additive. Brake thermal efficiency had increased and BSFC decreased with the additive in Mahua biodiesel. K. R. Patil et al [22] have conducted experiments on C. I. Engine with kerosene-diesel-diethyl ether and found an improvement in Brake thermal efficiency with the addition of DEE additive. The Smoke and CO emissions were reduced and $\mathrm{HC}$ emissions were increased compared to that of diesel. Amar Ibrahim [23] has studied the C.I. engines performance with waste cooking oil biodiesel by adding DEE with it. His results showed a decrease in BSFC, increase in thermal efficiency at $5 \%$ dee. With an increase in DEE to $10 \%$ reduced the thermal efficiency of the engine.

Based on the above literature, in the current work, Neem oil was selected to produce biodiesel and DEE was selected as additive.

\section{MATERIALS \& METHODS}

\section{A. Neem Oil}

The neem oil is extracted from the seeds of neem tree. It is an evergreen tree and its seeds have $25 \%$ to $45 \%$ oil yield. Many methods are followed for extracting the oil from neem fruits and seeds [23]. The oil can be extracted through pressing or through a process incorporating temperature controls.

\section{B. Bio Diesel Preparation}

The neem oil was purchased from local market. As the oil has high viscosity, it is important to reduce its viscosity to mix it with diesel. This was done in the laboratory by the process of base catalytic transesterification. One liter of Neem oil was heated to $80^{\circ} \mathrm{C}$ using hot plate stirring heater. $400 \mathrm{ml}$ of methanol was added with $1 \% \mathrm{NAOH}$ as catalyst and mixed well. Later the mixture was added into the neem oil at $80^{\circ} \mathrm{C}$ gradually. The heating and stirring process continued at that temperature for another one hour. Then the mixture carried over to separating funnel. After 24 hours, the bottom layer of glycerol in the separating funnel was separated out and the remaining oil was taken for the preparation of biodiesel.

\section{DiEthylEther}

It is an oxygenated additive with chemical formula $\left(\mathrm{C}_{2} \mathrm{H}_{5}\right)_{2} \mathrm{O}$. Oxygenated additives contain oxygen as a part of their chemical structure. For this study of experiments, Diethyl ether was procured from local chemical store for the laboratory purpose.

Table-I: Properties of Diethyl Ether

\begin{tabular}{|l|l|}
\hline Molar mass & 90.08 g.mol-1 \\
Appearance & clear liquid \\
Density & $713 \mathrm{~kg} / \mathrm{m}$ \\
Boiling point & $34.6^{\circ} \mathrm{C}$ \\
Melting point & $-116^{\circ} \mathrm{C}$ \\
Solubility in water & $6.05 \mathrm{gr} / 100 \mathrm{ml}$ \\
\hline
\end{tabular}

Table-II: Properties of Test fuels

\begin{tabular}{|c|c|c|c|c|c|}
\hline Properties & $\begin{array}{l}\text { Density } \\
\mathrm{Kg} / \mathrm{m}^{3}\end{array}$ & $\begin{array}{l}\text { Viscosity } \\
\mathrm{mm}^{2} / \mathrm{Sec}\end{array}$ & $\begin{array}{l}\text { Flash } \\
\text { point } \\
{ }^{0} \mathrm{C}\end{array}$ & $\begin{array}{l}\text { Fire } \\
\text { point } \\
{ }^{0} \mathrm{C}\end{array}$ & $\begin{array}{l}\text { Calorific } \\
\text { value } \\
\mathrm{KJ} / \mathrm{kg}\end{array}$ \\
\hline Diesel & 833 & 3.12 & 50 & 59.4 & 44000 \\
\hline $\begin{array}{l}\text { Neem oil } \\
\text { biodiesel }\end{array}$ & 874 & 5.2 & 150 & 158 & 39071 \\
\hline B10 & 836 & 4.17 & 84 & 89 & 41896 \\
\hline B20 & 845 & 4.47 & 93 & 98 & 40303 \\
\hline B10DEE10 & 827 & 4.06 & 78 & 82 & 42783 \\
\hline B10DEE20 & 821 & 3.84 & 73 & 76 & 43290 \\
\hline B20DEE10 & 837 & 4.18 & 84 & 91 & 41364 \\
\hline B20DEE20 & 828 & 3.92 & 81 & 87 & 41879 \\
\hline
\end{tabular}

\section{EXPERIMENTAL SETUP}

The experimental setup consists of a Variable compression ratio diesel engine with eddy current dynamometer as loading unit. The engine is a single cylinder water cooled 4-stroke engine of Kirloskar made. The figure shows the photographic view of the engine and the table shows the technical specifications of the engine.

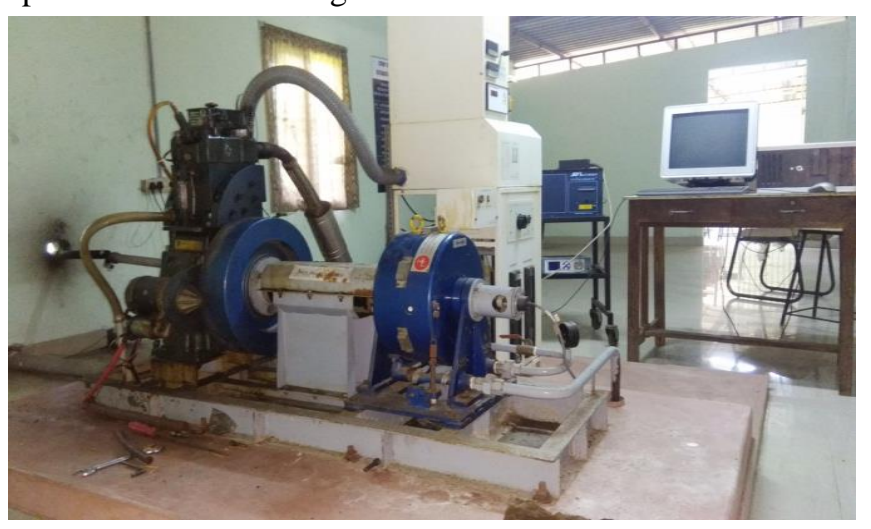

Fig.-I: Computerized VCR Engine Setup with Smoke meter and Gas analyzer. 
"IC Engine Soft LV" Software is used for the online performance evaluation. The emissions of carbon monoxide, Carbon dioxide, and hydrocarbons were measured with AVL Digas 444 gas analyzer. The smoke emission was measured with AVL Smoke analyzer.

\section{TABLE-III : TECHNICAL SPECIFICATIONS OF THE ENGINE}

\begin{tabular}{ll}
\hline Make & Kirloskar \\
Rated output & $3.5 \mathrm{KW}$ \\
Bore & $87.5 \mathrm{~mm}$ \\
Stroke & $110 \mathrm{~mm}$ \\
Compression ratio & $12: 1$ to $18: 1$ \\
Capacity & $661 \mathrm{cc}$ \\
Dynamometer arm length & \\
& $185 \mathrm{~mm}$ \\
Rated speed & $1500 \mathrm{rpm}$ \\
Engine loading unit & Eddy current dynamometer \\
\hline
\end{tabular}

\section{RESULTS AND DISCUSSION}

The experiments were carried out on the engine with diesel, neem oil blended with diesel as B10, B20 and the additive Diethyl ether (DEE) mixed with the blends as B10DEE10, B10DEE20, B20DEE10, and B20DEE20. The average results of the experiments that conducted three times were taken and the graphs plotted.

\section{A. Engine Performance}

\section{- BRAKE POWER}

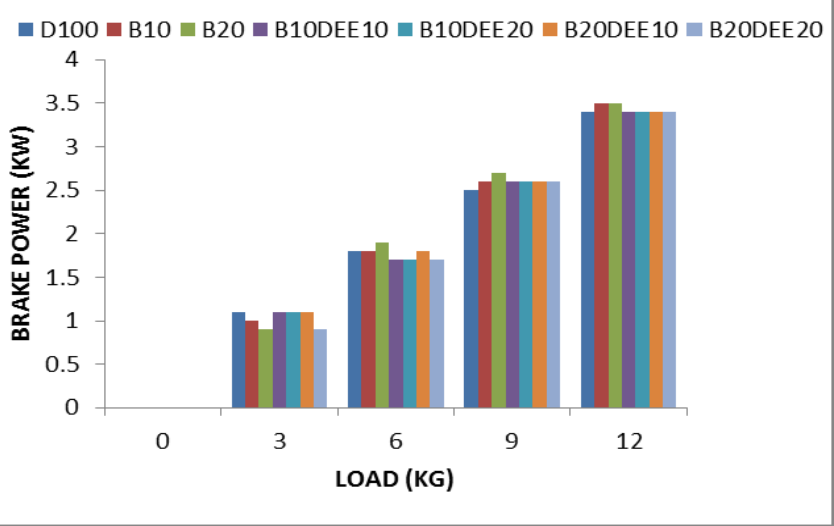

Fig.II: Variation of Brake power to load of Diesel and Test fuels

From the fig. it is observed that the brake power of the engine is higher for B10 and B20 compared to diesel. The addition of the DEE with the blends $\mathrm{B} 10$ and $\mathrm{B} 20$ have given same brake power as that of diesel.

\section{- BRAKE THERMAL EFFICIENCY}

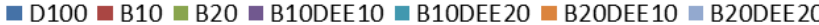

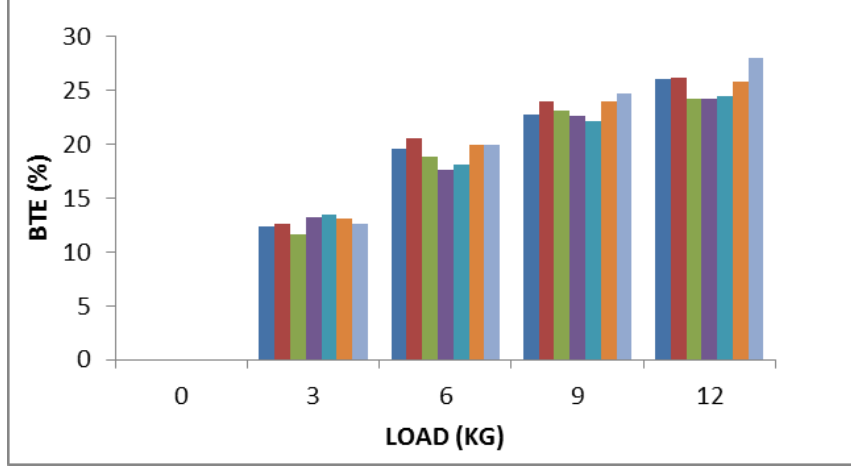

Fig.-III: Variation of Brake Thermal Efficiency to load of Diesel and Test fuels

From the fig. it is observed that the brake thermal efficiency with B10 is higher compared to diesel. The blend B20 produced low brake thermal efficiency but the addition of DEE i.e. B20DEE20 improved the brake thermal efficiency by $7.69 \%$ compared to diesel at full load. This may be due to the availability of oxygen content and the cetane number improvement with addition of DEE.

- BRAKE SPECIFIC FUEL CONSUMPTION

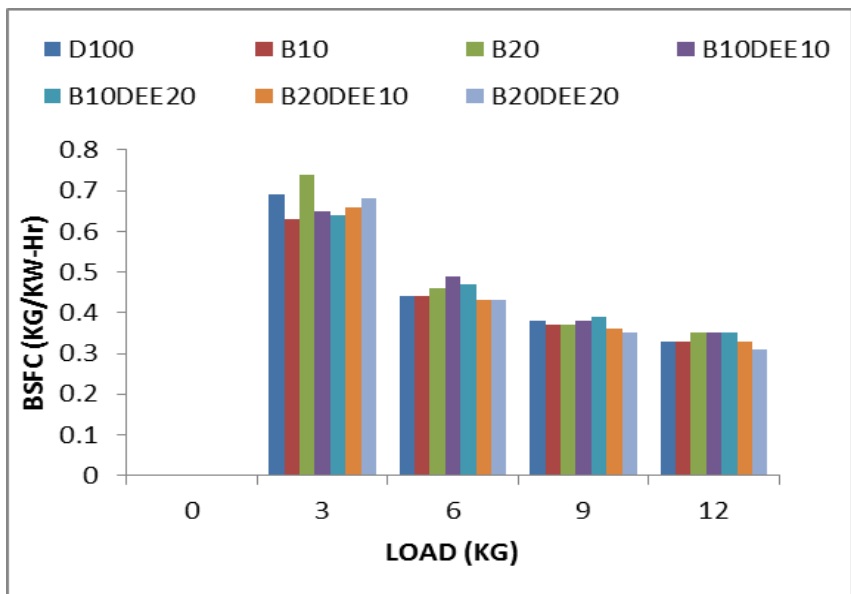

Fig.IV: Variation of Brake Specific Fuel Consumption to load of Diesel and Test fuels

The fig. shows that the fuel consumption is low with the blend B10 compared to the B20 and diesel. But the addition of DEE improved the fuel economy of the engine with B20 as there is a reduction of $6.06 \%$ in fuel consumption with B20DEE20 at full load. This could be due to the reduction of viscosity of fuel with additive than that of without additive.

\section{B. ENGINE EMISSIONS}

The carbon monoxide, carbon dioxide and hydrocarbons emissions at different test fuels were plotted from the experimental data and they are compared.

\section{- CARBON MONOXIDE}




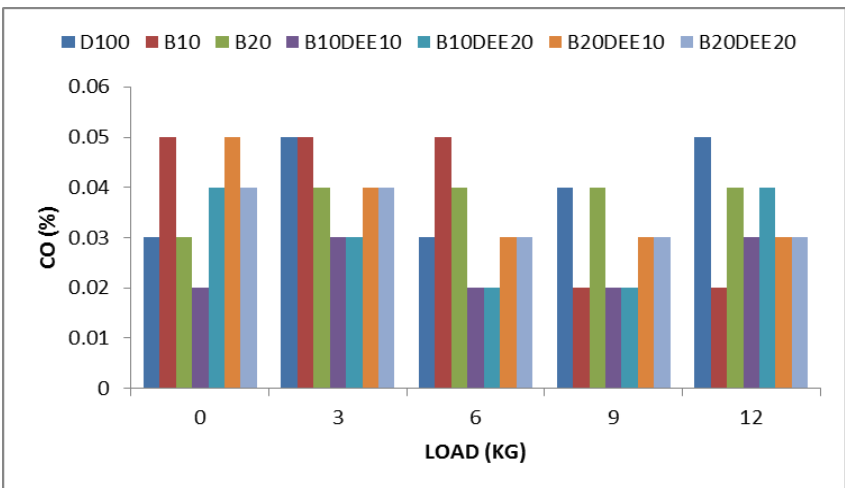

Fig.V: Variation of Carbon Monoxide to load of Diesel and Test fuels

The graph shows a slight increase in $\mathrm{CO}$ emissions with B10 at low loading condition. CO emissions of B20 are comparable to diesel at all loads. With B20DEE10 and B20DEE20 the CO emissions were reduced by $25 \%$ and $40 \%$ respectively at $3 / 4^{\text {th }}$ and full load compared to diesel.

\section{- CARBON DIOXIDE}

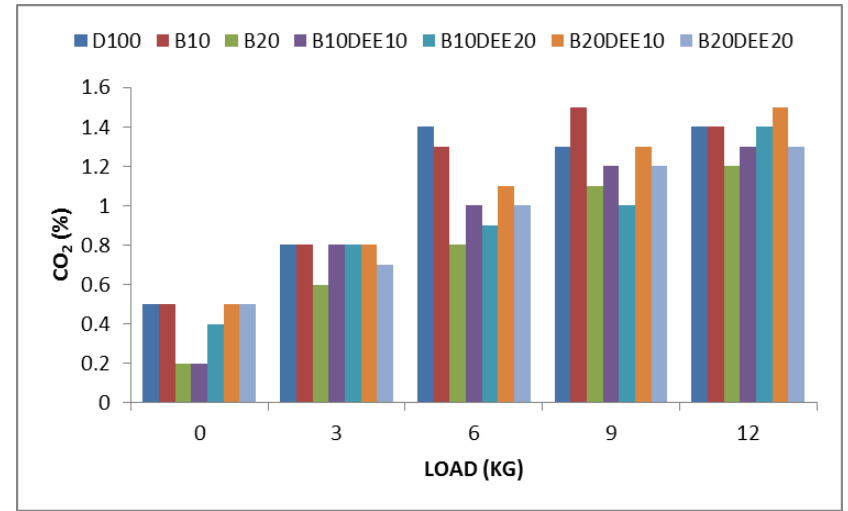

Fig.VI: Variation of Carbon dioxide to load of Diesel and Test fuels

The $\mathrm{CO}_{2}$ emissions were reduced with B20 considerably at all loads compared to diesel. The B20DEE20 given slight reduction in $\mathrm{CO}_{2}$ compared to diesel. The carbon dioxide emission of B10 was almost equal to diesel at all the loads.

\section{- HYDROCARBANS}

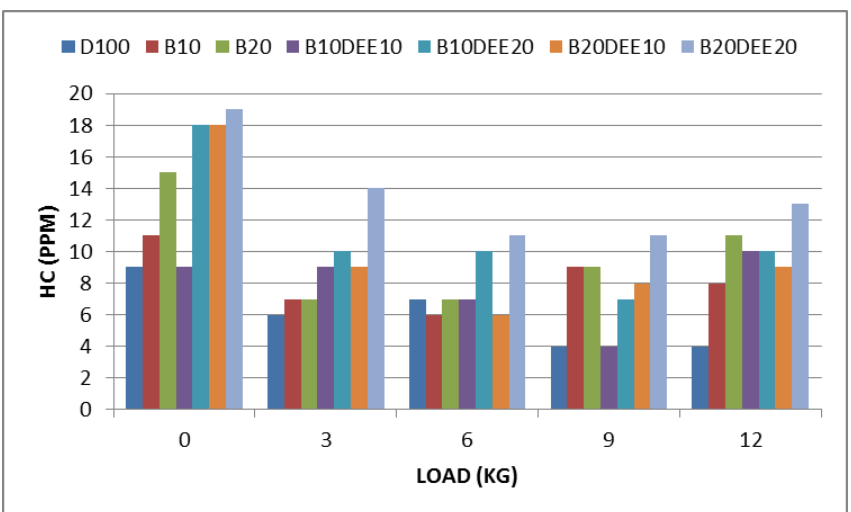

Fig.VII: Variation of Hydro Carbon emission to load of Diesel and Test fuels

The hydrocarbon emissions of all the blends of diesel-neem oil as well as the addition of DEE in the blends were higher than the diesel at all loads. It was observed from the fig that the HC emissions of B20DEE20 are far greater than the remaining test fuels. This could be due to the nature of DEE to evaporate easily from the cylinder during expansion stroke [20]. Among the rest of the blends, B10DEE10 produced low HC emissions.

\section{- SMOKE OPECITY}

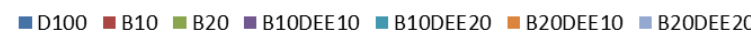

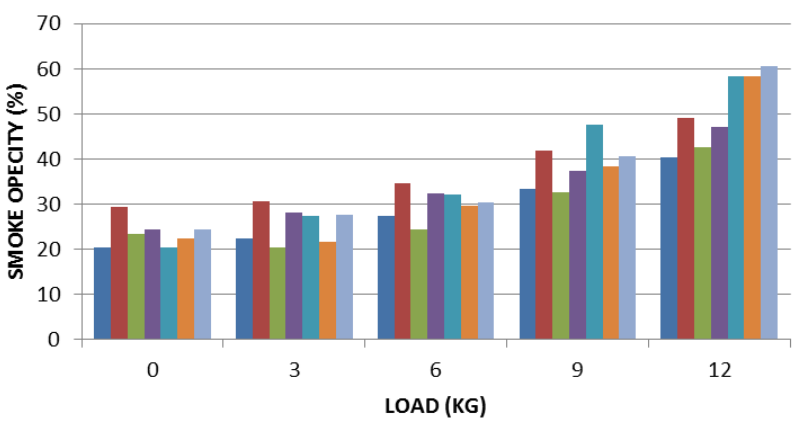

Fig.VIII: Variation of Smoke Opacity to load of Diesel and Test fuels

The smoke emissions of the engine with all the test fuels are higher than the diesel. This could be due to the problem aroused in atomization of fuel in the engine due to the high viscosity of the blends. Among all of the test fuels B20 showed the least smoke emissions next to diesel.

\section{CONCLUSION}

The performance and emission characteristics of a single cylinder C.I. VCR Engine were studied using diesel, methyl esters of neem oil, Diethyl ether as additive in methyl esters of neem oil. From the experimental data, the following conclusions were drawn:

1. The viscosity of the neem oil is reduced by blending it with diesel after transesterification.

2. The brake power of the engine is improved with B10, B20. The usage of the DEE additive with these blends given same power as that of diesel.

3. The brake thermal efficiency is increased by $5.28 \%$ with B10 and 7.69\% with B20DEE20 compared with diesel.

4. The brake specific fuel consumption of the engine is reduced by $6.06 \%$ with the use of B20DEE20.

5. The carbon monoxide emissions are reduced by 25\% with B20DEE10 and 40\% with B20DEE20 compared to diesel.

6. The carbon dioxide emissions are reduced with B10, B20 and B20DEE20.

7. The emissions of HC and Smoke are increased with the neem methyl esters as well as with the addition of DEE into them compared to diesel.

Finally, the experimental results indicated that the neem oil biodiesel B10 can be used as alternative to the diesel. Also B20DEE20 can be used as the alternative fuel to improve the performance and reduce the emissions of the C.I. Engine without any modification of the existing engines.

\section{REFERENCES}

1. Rao Venkateswara T, Prabhakar Rao G, Hema Chandra Reddy K Experimental investigation of pongamia, jatropha and neem methy esters as biodiesel on C.I.Engine. Jordan J Mech Ind Eng 2008; $2: 117-22$ 
2. T. Balamurugan, A. Arun, G.B. Sathishkumar Biodiesel derived from corn oil - A fuel substitute for diesel. Renewable and Sustainable Energy Reviews 94 (2018) 772-778.

3. R. El-Araby , Ashraf Amin, A.K. El Morsi, N.N. El-Ibiari, G.I. El-Diwani Study on the characteristics of palm oil-biodiesel-diesel fuel blend. Egyptian Journal of Petroleum (2017).

4. M Canakci Performance and emissions characteristics of biodiesel from soybean oil. Proc. IMechE Vol. 219 Part D: J. Automobile Engineering (2005)915-922.

5. V. Vara Prasad Performance Of 4 Stroke Diesel Engine Using Coconut Oil As Biofuel Material. Materials Today: Proceedings 4 (2017) 5312-5319.

6. Md. Nurun Nabi, Md. Mustafizur Rahman, Md. Shamim Akhter Biodiesel from cotton seed oil and its effect on engine performance and exhaust emissions. Applied Thermal Engineering 29 (2009) 2265-2270.

7. https://en.wikipedia.org/wiki/Food_vs._fuel

8. M.M. Gui, K.T. Lee, S. Bhatia Feasibility of edible oil vs. non-edible oil vs. waste edible oil as biodiesel feedstock . Energy 33 (2008) 16461653.

9. AyhanDemirbas Comparison of transesterification methods for production of biodiesel from vegetable oils and fats. Energy Conversion and Management 49(1):125-130

10. http://www.etipbioenergy.eu/value-chains/conversion-technologies/co nventional-technologies/transesterification-to-biodiesel

11. S.Jaichandar and K. Annamalai Jatropha oil methyl ester as diese engine fuel - an experimental investigation. International Journal of Automotive and Mechanical Engineering 13(1)2016 3248-3261

12. T. Venkateswara Rao, G. Prabhakar Rao, and K. Hema Chandra Reddy Experimental Investigation of Pongamia, Jatropha and Neem Methyl Esters as Biodiesel on C.I. Engine. Jordan J Mech Ind Eng 2008; 2:117-22.

13. Jayashri N. Nair *, Ajay Kumar Kaviti, Arun Kumar Daram Analysis of performance and emission on compression ignition engine fueled with blends of Neem biodiesel. Egyptian Journal of Petroleum (2017) 26, 927-931

14. Y.V.Hanumantha Rao, Ram Sudheer Voleti, A.V.Sitarama Raju and P.Nageswara Reddy Experimental investigations on jatropha biodiesel and additive in diesel engine

15. Performance Of 4 Stroke Diesel Engine Using Coconut Oil As Biofuel Material V. Vara Prasad

16. Biodiesel from cotton seed oil and its effect on engine performance and exhaust emissions Md. Nurun Nabi *, Md. Mustafizur Rahman, Md. Shamim Akhter

17. Study on the characteristics of palm oil-biodiesel-diesel fuel blendq R. El-Araby a , Ashraf Amin a , A.K. El Morsi b,^ , N.N. El-Ibiari a , G.I. El-Diwania

18. The impacts on combustion, performance and emissions of biodiesel by using additives in directinjection diesel engine M. Vijay Kumar *, A. Veeresh Babu, P. Ravi Kumar

19. A comparative study on performance, combustion and emission characteristics of diesel engine fuelled by biodiesel blends with and without an additive M. Mohamed Musthafa *, T. Ashok Kumar, T. Mohanraj, R. Chandramouli

20. Emission and performance improvement analysis of biodiesel-diesel blends with additives S.Imtenana, *, H.H. Masjuki a, M. Varmana, M.I. Arbaba, H. Sajjada, I.M. Rizwanul Fattaha, M.J. Abedina , Abu Saeed Md. Hasibb

21. Experimental Investigation on Performance and Emission Characteristics of a Diesel Engine Fuelled with Mahua Biodiesel Using Additive Swarup Kumar Nayaka , Bhabani Prasanna Pattanaika,*

22. Experimental investigation of CI engine combustion, performance and emissions in DEE-kerosene-diesel blends of high DEE concentration K.R. Patila,b, $\Uparrow$, S.S. Thipse

23. An experimental study on using diethyl ether in a diesel engine operated with diesel-biodiesel fuel blend Amr Ibrahim

24. https://www.agrifarming.in/neem-oil-extraction-methods-process 